\title{
Pulmonary tuberculosis among contacts of patients with tuberculosis in an urban Indian population
}

\author{
RAJ KUMAR, M SARAN, B L VERMA, AND R N SRIVASTAVA \\ From the Department of Social and Preventive Medicine, Maharani Laxmi Bai Medical College, Jhansi, India
}

SUMMARY The study was conducted among 1810 contacts of 50 index "cases"/“suspects" of pulmonary tuberculosis including 312 household and 1498 neighbourhood contacts in the Jhansi city of Uttar Pradesh. The overall prevalence of radiologically active and bacteriologically confirmed tuberculosis was $2 \cdot 9 \%$ and $1 \cdot 1 \%$. The prevalence rates of radiologically active and bacteriologically confirmed disease, although comparatively high in both the contact groups, were significantly higher in household $(5 \cdot 4 \%$ and $2.6 \%)$ than in neighbourhood contacts $(2 \cdot 3 \%$ and

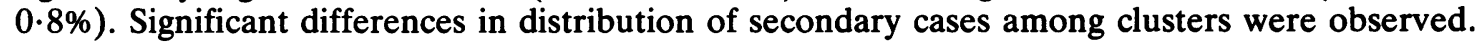
Although higher prevalence rates were found in contacts of sputum positive source than in contacts of sputum negative source in both the contact groups, the statistical difference was observed to be insignificant. Case yield among contact symptomatics was $80.0 \%$ (30.8\% cases and $49 \cdot 2 \%$ suspects).

Various studies conducted among close family contacts have proved that there is a greater risk to those who remain in contact with the patients with pulmonary tuberculosis. ${ }^{1-8}$ Nevertheless, the zone of influence of a case cannot be limited to the family members only. It extends beyond the case households, to neighbourhood households according to the degree of closeness. Moreover, though it is a well established fact that "cases" of pulmonary tuberculosis pose high risk to their contacts, the risk caused by "suspects" cannot be overlooked because some of the genuine cases of pulmonary tuberculosis may not show tubercule bacilli in their sputum at every stage of the disease, even though they are harbouring bacilli.

The present study, a slightly modified evaluation of contact examination limited to only symptomatic contacts for case detection, aims at finding out the prevalence of tuberculosis among the household as well as neighbourhood contacts of those patients with tuberculosis who are registered at the district tuberculosis centre, Jhansi, and the case yield among symptomatic contacts.

\section{Material and methods}

\section{STUDY AREA}

The study was carried out in the urban and slum localities of Jhansi city in south west Uttar Pradesh and the headquarters of Jhansi division. The study area is about $7 \mathrm{~km}$ from Maharani Laxmi Bai Medical College, Jhansi, and spread over a radius of $5 \mathrm{~km}$. The district tuberculosis centre, situated in the middle of the city, functions as a core of the National Tuberculosis Control Programme covering the urban as well as the rural population (around 900000 ) of the district. The district tuberculosis centre has a health team of three medical officers, two $x$ ray technicians, one laboratory technician, two staff nurses, two health visitors, and non-medical staff. The centre is equipped with a miniature $x$ ray unit, a laboratory, 10 indoor beds, and transport facilities. Up to June 1982 about 2000 cases of pulmonary tuberculosis were registered there for domiciliary treatment; of these, about 400 cases were from Jhansi city only. Besides detection of cases among symptomatics attending the outpatient department and providing treatment for them, the centre also gives BCG vaccination to those at risk (0-19 years, undertakes Mantoux test to child contacts, and provides hospital treatment to serious patients.

\section{METHODS}

In view of limited resources and time a contact population of 50 cases was considered for the study purpose. Visualising some field difficulties such as non-availability of the respondents, their refusals, and overlapping, 80 cases out of those registered at 
the district tuberculosis centre from Jhansi city only were selected after simple random sampling without replacement. ${ }^{7}$ These selected cases were primarily called index cases or index suspects and their families, index case/suspect families. Those having sputum positive for Mycobacterium tuberculosis on smear examination were taken as cases and those with negative smear but having suggestive shadows in chest skiagrams were reckoned as suspects for the present purpose. ${ }^{8}$ Furthermore, the term cases has been used in the text, at times, to include cases as well as suspects.

Case clusters were formed on the spot during the survey by enlisting the index case family as a nucleus and five other adjacent families around the index case family as the contact population. When more than one registered case was present in a cluster, the oldest sufferer was considered to be the index case and the rest were taken as contacts. In this way 50 clusters comprising 300 families were studied. The family members of index case families were taken as close family contacts and those from neighbouring families were considered as neighbourhood contacts.

The study started on 17 July 1982 and continued until 16 January 1983 . In the survey team were one male and one female social worker besides the investigator (medical). During the survey, after location and confirmation of the index case, particulars of the patient and the family including those with symptoms, if any, were recorded. Similarly other families of the cluster were also contacted and interviewed in order to collect relevant information. The individuals were considered as symptomatics if they had chest symptoms such as cough, continuous fever, chest pain lasting for four weeks or more, or haemoptysis, along with constitutional symptoms such as lassitude, loss of weight, emotional irritability, and insomnia, if any.

An effort was made to contact all the individuals of the family, especially those with symptoms. This, however, required repeated and special visits to some families where symptomatic contacts had not been contacted in previous visits. All symptomatic contacts were motivated to come to the district tuberculosis centre on routine working days for diagnostic investigations such as sputum examination for acid fast bacilli and miniature radiography. The investigations were performed by the investigator himself at the centre on working days from 12 noon to $2 \mathrm{pm}$.

Spot collection of sputum from symptomatic contacts was done in waxed cartons under supervision after proper instruction. When sputum was not present, a laryngeal swab was taken. Smears were made after careful selection of necrotic material and stained by Ziehl Neelsen's technique. ${ }^{9}$ Stained smears were examined thoroughly under oil immersion for 5-10 minutes before they were declared negative.

Each symptomatic contact had a $70 \mathrm{~mm}$ miniature radiograph of the chest (posteroanterior view) taken in the miniature $x$ ray unit. Both the investigator and the district tuberculosis officer read the films, first separately and then together before coming to a final conclusion. Diagnostic standards given by the Tuberculosis Association of India ${ }^{10}$ were followed for diagnosis. Whenever the miniature $x$ ray findings seemed doubtful, the diagnosis was decided with the help of a full size $x$ ray film paid for by the patient.

\section{Results}

The studied contact population of 1810 individuals included 312 household contacts from 50 index families and 1498 neighbourhood contacts from 250 neighbouring families. Out of 1810 contacts, 72 had symptoms. Attempts were made to investigate them all in order to arrive at a definitive diagnosis. Three of them, however, did not cooperate. Furthermore, four had only lymphadinitis, but this diagnosis could not be confirmed owing to lack of appropriate facilities at the centre. The analysis, therefore, after ignoring these seven was limited to 65 symptomatics only.

The prevalence rates of radiologically active as well as bacteriologically confirmed pulmonary tuberculosis were worked out for household and neighbourhood contacts separately. All the acid fast bacilli positive cases were also radiologically positive. Overall prevalence rates of radiologically active and bacteriologically confirmed pulmonary tuberculosis were $2.9 \%$ and $1.1 \%$ (table 1 ). The prevalence rates of $x$ ray positive tuberculosis in household contacts and neighbourhood contacts were $5 \cdot 4 \%$ and $2 \cdot 3 \%$, with statistically significant differences $(p<0.01)$. Prevalence rate of acid fast bacilli positive tuberculosis was $2.6 \%$ in household and $0.8 \%$ in neighbourhood contacts (table 1 ). The difference in this case was also statistically significant $(p<0 \cdot 01)$.

Increasing trend in age wise prevalence of the disease was observed in both the contact groups with statistically significant differences $(p<0.001)$ between the two, although slight fluctuations were present in all three categories (table 1). Prevalence rates of the disease were also studied for the two sexes separately (table 2 ). The overall prevalence of $x$ ray positive and acid fast bacilli positive pulmonary tuberculosis was $1.8 \%$ and $0.9 \%$ in men and women respectively. The difference was significant $(p<0 \cdot 05)$. Moreover, prevalence rates based on radiologically active and bacteriologically confirmed cases were higher in women than men in both contact groups, household as well as neighbourhood (table 
Table 1 Age specific prevalence rates of pulmonary tuberculosis based on radiologically active and bacteriologically confirmed cases among contacts

\begin{tabular}{|c|c|c|c|c|c|c|c|c|c|c|c|c|}
\hline \multirow[b]{3}{*}{$\begin{array}{l}\text { Age } \\
\text { group } \\
\text { (y) }\end{array}$} & \multicolumn{5}{|l|}{ Household } & \multicolumn{5}{|c|}{ Neighbourhood } & \multirow{2}{*}{\multicolumn{2}{|c|}{$\begin{array}{l}\text { Overall } \\
\text { prevalence rate } \\
(\%)\end{array}$}} \\
\hline & \multirow[b]{2}{*}{$\begin{array}{l}\text { Contact } \\
\text { population }\end{array}$} & \multicolumn{2}{|c|}{$x$ ray positive } & \multicolumn{2}{|c|}{$A F B$ positive } & \multirow[b]{2}{*}{$\begin{array}{l}\text { Contact } \\
\text { population }\end{array}$} & \multicolumn{2}{|c|}{$x$ ray positive } & \multicolumn{2}{|c|}{$A F B$ positive } & & \\
\hline & & $\begin{array}{l}\text { No of } \\
\text { cases }\end{array}$ & $\begin{array}{l}\text { Prevalence } \\
\text { rate } \\
(\%)\end{array}$ & $\begin{array}{l}\text { No of } \\
\text { cases }\end{array}$ & $\begin{array}{l}\text { Prevalence } \\
\text { rate } \\
(\%)\end{array}$ & & $\begin{array}{l}\text { No of } \\
\text { cases }\end{array}$ & $\begin{array}{l}\text { Prevalence } \\
\text { rate } \\
(\%)\end{array}$ & $\begin{array}{l}\text { No of } \\
\text { cases }\end{array}$ & $\begin{array}{l}\text { Prevalence } \\
\text { rate } \\
(\%)\end{array}$ & $\begin{array}{l}x \text { ray } \\
\text { positive }\end{array}$ & $\begin{array}{l}A F B \\
\text { positive }\end{array}$ \\
\hline $0-4$ & 142 & 5 & $3 \cdot 2$ & $\mathrm{Nil}$ & Nil & 586 & 5 & 0.9 & 1 & 0.2 & $1 \cdot 4$ & $0 \cdot 1$ \\
\hline $15-44$ & 130 & 10 & $7 \cdot 7$ & 4 & $3 \cdot 1$ & 695 & 22 & $3 \cdot 2$ & 9 & $1 \cdot 3$ & 3.9 & $1 \cdot 1$ \\
\hline$\geqslant 45$ & 40 & 2 & $5 \cdot 0$ & 4 & $10 \cdot 0$ & 217 & 8 & $3 \cdot \overline{7}$ & 2 & 0.9 & $3 \cdot 9$ & 0.8 \\
\hline Total & 312 & 17 & $5 \cdot 4$ & 8 & $2 \cdot 6$ & 1498 & 35 & $2 \cdot 3$ & 12 & 0.8 & $2 \cdot 9$ & $1 \cdot 1$ \\
\hline
\end{tabular}

Statistical significance:

(a) Overall prevalence: (a) $x$ ray positive, $\chi^{2}=9.90$, $\mathrm{df}=2, \mathrm{p}<0.01$,

(b) Type of contacts: (a) $x$ ray positive, $t=3.01, p<0.01$

(b) AFB positive, $\chi^{2}=35 \cdot 04$. $\mathrm{df}=2, \mathrm{p}<0.0001$.

AFB = Acid fast bacilli.

(b) AFB positive, $\mathrm{t}=2 \cdot 80, \mathrm{p}<0 \cdot 01$.

Table 2 Sex specific prevalence rates of pulmonary tuberculosis based on radiologically active and bacteriologically confirmed cases among contacts

\begin{tabular}{|c|c|c|c|c|c|c|c|c|c|c|c|c|}
\hline \multirow[b]{3}{*}{$\operatorname{Sex}$} & \multicolumn{5}{|l|}{ Household } & \multicolumn{5}{|c|}{ Neighbourhood } & \multirow{2}{*}{\multicolumn{2}{|c|}{$\begin{array}{l}\text { Overall } \\
\text { prevalence rate } \\
(\%)\end{array}$}} \\
\hline & \multirow[b]{2}{*}{$\begin{array}{l}\text { Contact } \\
\text { population }\end{array}$} & \multicolumn{2}{|c|}{$x$ ray positive } & \multicolumn{2}{|c|}{$A F B$ positive } & \multirow[b]{2}{*}{$\begin{array}{l}\text { Contact } \\
\text { population }\end{array}$} & \multicolumn{2}{|c|}{$x$ ray postive } & \multicolumn{2}{|c|}{$A F B$ positive } & & \\
\hline & & $\begin{array}{l}\text { No of } \\
\text { cases }\end{array}$ & $\begin{array}{l}\text { Prevalence } \\
\text { rate } \\
(\%)\end{array}$ & $\begin{array}{l}\text { No of } \\
\text { cases }\end{array}$ & $\begin{array}{l}\text { Prevalence } \\
\text { rate } \\
(\%)\end{array}$ & & $\begin{array}{l}\text { No of } \\
\text { cases }\end{array}$ & $\begin{array}{l}\text { Prevalence } \\
\text { rate } \\
(\%)\end{array}$ & $\begin{array}{l}\text { No of } \\
\text { cases }\end{array}$ & $\begin{array}{l}\text { Prevalence } \\
\text { rate } \\
(\%)\end{array}$ & $\begin{array}{l}x \text { ray } \\
\text { positive }\end{array}$ & $\begin{array}{l}A F B \\
\text { positive }\end{array}$ \\
\hline Male & 164 & 5 & $3 \cdot 0$ & 3 & $1 \cdot 8$ & 793 & 12 & $1 \cdot 5$ & 6 & 0.7 & $1 \cdot 8$ & 0.9 \\
\hline Female & 148 & 12 & $8 \cdot 1$ & 5 & 3.4 & 705 & 23 & $3 \cdot 3$ & 6 & 0.8 & $4 \cdot 1$ & $1 \cdot 3$ \\
\hline Total & 312 & 17 & $5 \cdot 4$ & 8 & $2 \cdot 6$ & 1498 & 35 & $2 \cdot 3$ & 12 & 0.8 & $2 \cdot 9$ & $1 \cdot 1$ \\
\hline
\end{tabular}

Statistical significance of overall rates between sexes for:

(a) $x$ ray positive: $\chi^{2}=8.50, \mathrm{df}=1, \mathrm{p}<0.005$,

(b) AFB positive: $\chi^{2}=6.48, \mathrm{df}=1, \mathrm{p}>0.05$.

AFB $=$ Acid fast bacilli.

$2)$. The differences in rates between the two sexes were significant for $x$ ray postive cases $(p<0 \cdot 05)$ but insignificant for acid fast bacilli positives $(p>0 \cdot 05)$.

Prevalence of pulmonary tuberculosis was also assessed according to the bacteriological status of the source. Although it varied in the two contact groups, it did not differ significantly among the contacts of sputum positive and sputum negative sources. The overall prevalence rates and also the prevalence rates of the disease in the two contact groups were a little higher among the contacts having a sputum positive source than those having a sputum negative source (table 3). There was, however, no association between prevalence rates and nature of source in both the contact groups $(p>0 \cdot 05)$.

Analysis showed that some of the case clusters had accumulation of cases. Out of 50 case clusters studied, 18 clusters $(36 \cdot 0 \%)$ were with only index case or suspect, 19 clusters $(38.0 \%)$, however, were with one case, eight clusters $(16 \cdot 0 \%)$ with two cases, and five clusters $(10 \cdot 0 \%)$ with three or more cases as well as the index case or suspect. The statistical difference in distribution of secondary cases among clusters was significant $(p<0 \cdot 01)$. The study sample of 50 clusters included 20 case clusters and 30 suspect clusters. Table 4 shows distribution of secondary cases in both types of clusters. Secondary cases of tuberculosis were distributed in index case clusters and index suspect clusters withou: any significant statistical difference $(p>0.05)$.

Case yield was found to be remarkably high among those with symptoms. Analysis, in depth, showed that overall case/suspect yield among symptomatics was $80-94.4 \%$ in household and $74.4 \%$ in neighbourhood contact symptomatics, including $38 \cdot 8 \%$ cases and $49 \cdot 2 \%$ suspects (table 5 ). Analysis showed that case yield was considerably high in household symptomatic contacts. Differences in rates between two types of contacts, worked out separately, for cases and overall cases/suspects were statistically insignificant $(\mathrm{p}>0.05)$. 
Table 3 Index cases and prevalence rates of pulmonary tuberculosis by bacteriological status of the source

\begin{tabular}{|c|c|c|c|c|c|c|c|c|c|}
\hline \multirow[b]{2}{*}{$\begin{array}{l}\text { Bacteriological } \\
\text { status of source }\end{array}$} & \multicolumn{2}{|c|}{ Index cases* } & \multicolumn{3}{|l|}{ Household } & \multicolumn{3}{|c|}{ Neighbourhood } & \multirow{2}{*}{$\begin{array}{l}\text { Overall } \\
\text { prevalence } \\
\text { rate } \\
(\%)\end{array}$} \\
\hline & No & $\%$ & $\begin{array}{l}\text { Contact } \\
\text { population }\end{array}$ & $\begin{array}{l}\text { No of } \\
\text { cases }\end{array}$ & $\begin{array}{l}\text { Prevalence } \\
\text { rate } \\
(\%)\end{array}$ & $\begin{array}{l}\text { Contact } \\
\text { population }\end{array}$ & $\begin{array}{l}\text { No of } \\
\text { cases }\end{array}$ & $\begin{array}{l}\text { Prevalence } \\
\text { rate } \\
(\%)\end{array}$ & \\
\hline \multirow{2}{*}{$\begin{array}{c}\text { Sputum AFB } \\
\text { positive } \\
\text { Sputum AFB } \\
\text { negative }{ }^{\dagger}\end{array}$} & 20 & $40 \cdot 0$ & 129 & 10 & $7 \cdot 8$ & 600 & 17 & $2 \cdot 8$ & $3 \cdot 7$ \\
\hline & 30 & $60 \cdot 0$ & 183 & 7 & 3.8 & 898 & 18 & $2 \cdot 0$ & $2 \cdot 3$ \\
\hline Total & 50 & $100 \cdot 0$ & 312 & 17 & $5 \cdot 4$ & 1498 & 35 & $2 \cdot 3$ & $2 \cdot 9$ \\
\hline
\end{tabular}

*Includes index cases as well as suspects.

tx ray positives.

Statistical significance of:

(a) Overall prevalence rate by bacteriological status of the source: $\chi^{2}=3.06$, df $=1, p>0.05$.

(b) Association of rates by bacteriological status of source and type of contact population: $\chi^{2}=3.67, \mathrm{df}=2, \mathrm{p}>0.05$.

AFB = Acid fast bacilli.

Table 4 Index case/suspect clusters showing distribution of secondary cases (sputum postive as well as $x$ ray positive). (Figures in parentheses represent percentages).

\begin{tabular}{|c|c|c|c|c|c|c|c|c|c|c|}
\hline \multirow[b]{2}{*}{ Clusters } & \multicolumn{2}{|c|}{$\begin{array}{l}\text { Without } \\
\text { secondary case }\end{array}$} & \multicolumn{2}{|c|}{$\begin{array}{l}\text { With } H H \\
\text { secondary case }\end{array}$} & \multicolumn{2}{|c|}{$\begin{array}{l}\text { With NBHD } \\
\text { secondary case }\end{array}$} & \multicolumn{2}{|c|}{$\begin{array}{l}\text { With } H H \& \text { \&BHD } \\
\text { secondary case }\end{array}$} & \multicolumn{2}{|l|}{ Total } \\
\hline & No & $\%$ & No & $\%$ & No & $\%$ & No & $\%$ & No & $\%$ \\
\hline $\begin{array}{l}\text { Index case } \\
\text { clusters }\end{array}$ & $\begin{array}{c}7 \\
(35 \cdot 0)\end{array}$ & 38.9 & $\begin{array}{l}3 \\
(15 \cdot 0)\end{array}$ & $50 \cdot 0$ & $\begin{array}{c}6 \\
(30 \cdot 0)\end{array}$ & $30 \cdot 0$ & $\begin{array}{c}4 \\
(20 \cdot 0)\end{array}$ & $66 \cdot 6$ & $\begin{array}{c}20 \\
(100 \cdot 0)\end{array}$ & $40 \cdot 0$ \\
\hline $\begin{array}{l}\text { Index suspect } \\
\text { clusters }\end{array}$ & $\begin{array}{c}11 \\
(36 \cdot 7)\end{array}$ & $61 \cdot 1$ & $\stackrel{3}{(10 \cdot 0)}$ & $50 \cdot 0$ & $\begin{array}{l}14 \\
(46 \cdot 7)\end{array}$ & $70 \cdot 0$ & $\begin{array}{l}2 \\
(6 \cdot 6)\end{array}$ & 33.4 & $\begin{array}{c}30 \\
(100 \cdot 0)\end{array}$ & $60 \cdot 0$ \\
\hline Total & $\begin{array}{c}18 \\
(36 \cdot 0)\end{array}$ & $100 \cdot 0$ & $\begin{array}{c}6 \\
(12 \cdot 0)\end{array}$ & $100 \cdot 0$ & $\begin{array}{l}20 \\
(40 \cdot 0)\end{array}$ & $100 \cdot 0$ & $\begin{array}{c}6 \\
(12 \cdot 0)\end{array}$ & $100 \cdot 0$ & $\begin{array}{c}50 \\
(100 \cdot 0)\end{array}$ & $100 \cdot 0$ \\
\hline
\end{tabular}

HH = Household.

NBHD = Neighbourhood.

Statistical significance of distribution of secondary cases by: Type of clusters: $\chi^{2}=0 \cdot 14, \mathrm{df}=1, \mathrm{p}>0 \cdot 05$.

Table 5 Case yield among symptomatic contacts by type of contact population

\begin{tabular}{|c|c|c|c|c|c|c|c|c|}
\hline \multirow[b]{2}{*}{$\begin{array}{l}\text { Contact } \\
\text { group }\end{array}$} & \multicolumn{2}{|c|}{$\begin{array}{l}\text { Symptomatics } \\
\text { studied }\end{array}$} & \multicolumn{5}{|c|}{ Secondary cases/suspects } & \multirow[b]{2}{*}{$\begin{array}{l}\text { Overall cases } \\
\text { suspects per } \\
100 \text { symptomatics }\end{array}$} \\
\hline & $\begin{array}{l}\text { No of } \\
\text { cases }\end{array}$ & $\%$ & $\begin{array}{l}\text { No of } \\
\text { cases }\end{array}$ & $\begin{array}{l}\text { Cases } \\
\text { per } 100 \\
\text { symptomatics }\end{array}$ & $\begin{array}{l}\text { No of } \\
\text { suspects }\end{array}$ & $\begin{array}{l}\text { Suspects } \\
\text { per } 100 \\
\text { symptomatics }\end{array}$ & $\begin{array}{l}\text { Total No of } \\
\text { cases/ } \\
\text { suspects }\end{array}$ & \\
\hline $\begin{array}{l}\text { Household } \\
\text { Neighbourhood }\end{array}$ & $\begin{array}{l}18 \\
47\end{array}$ & $\begin{array}{l}27 \cdot 7 \\
72 \cdot 3\end{array}$ & $\begin{array}{r}8 \\
12\end{array}$ & $\begin{array}{l}44 \cdot 5 \\
25 \cdot 5\end{array}$ & $\begin{array}{r}9 \\
23\end{array}$ & $\begin{array}{l}50 \cdot 0 \\
48 \cdot 9\end{array}$ & $\begin{array}{l}17 \\
35\end{array}$ & $\begin{array}{l}94 \cdot 4 \\
74 \cdot 4\end{array}$ \\
\hline Total & 65 & $100 \cdot 0$ & 20 & $30 \cdot 8$ & 35 & $49 \cdot 2$ & 52 & $80 \cdot 0$ \\
\hline
\end{tabular}

Statistical significance of:

(a) Overall cases/suspects yield by type of contacts: $t=1 \cdot 76, p>0.05$.

(b) Case yield by type of contacts: $t=1.45, p>0.05$. 


\section{Discussion}

High prevalence rates of radiologically active as well as bacillary tuberculosis among family contacts varying from $3 \cdot 3 \%$ to $10.0 \%$ and $1 \cdot 3 \%$ to $4 \cdot 2 \%$ have been reported from different parts of the world including India..$^{2-4}$ The discrepancies as shown from reviewed findings largely reflect the different criteria and methods adopted by different workers and, to some extent, are due to varied epidemiological situations. The present study showed more or less similar prevalence of active $(5 \cdot 4 \%)$ and bacillary $(2.6 \%)$ tuberculosis among the household contacts. The present prevalence rates might be rather lower than the actual ones because in the present study only symptomatic contacts were investigated. Furthermore, even some cases without symptoms might have escaped the examination. Nevertheless, most of the similar other contact studies, on the other hand, have screened all the contact population by radiography, culture, and repeated sputum examination. Hence, it is easy to believe that the case yield in these studies is considerably higher than the present one.

The present study showed a considerably higher prevalence of active $(5 \cdot 4 \%)$ and bacillary $(2 \cdot 6 \%)$ tuberculosis among household contacts than in the general population; the prevalence rates in the general population often vary from $0.8 \%$ to $2 \cdot 1 \%$ and from $0.2 \%$ to $0.8 \%$ in different parts of the country. $.^{11} \cdot-16$ The above two types of prevalence rates of tuberculosis $(2.3 \%$ and $0.8 \%)$ among neighbourhood contacts have been found to be close to the upper limits of rates in the general population. On the basis of infection rates among child contacts, Nair et al reported that the influence of cases of tuberculosis in the neighbourhood, though it may extend up to several households, usually remains highest in the first neighbourhood on either side of the case household. ${ }^{17}$ The present study gave a fairly high prevalence of active $(2 \cdot 3 \%)$ and bacillary $(0 \cdot 8 \%)$ tuberculosis among contacts of the first household.

Various authors have reported varying prevalence rates of pulmonary tuberculosis by age in contacts of patients with tuberculosis. ${ }^{1-46}$ We also found this variability in prevalence of tuberculosis for different age groups. The disease was more prevalent in the middle aged and elderly than in children. It appears therefore that tuberculosis, although highly prevalent in different age groups, especially in household contacts, is more prevalent in the middle aged and elderly who might have been infected many years ago. We believe that continuous superinfection in the host already having a tuberculosis infection often precipitates the adult type of tuberculosis in those who remain in the vicinity of the case.

Some of the studies conducted among family contacts have reported significantly higher prevalence of disease in women. ${ }^{23}$ In contrast, however, Ramkrishnan et al in their investigation observed a higher prevalence of disease in men. ${ }^{4}$ In the present study the overall prevalence rates based on radiologically active $(4 \cdot 8 \%)$ and bacillary $(1.5 \%)$ tuberculosis were much higher in female contacts than male contacts $(1.8 \%$ and $0.9 \%)$. The prevalence rates in both contact groups were significantly higher in women than in men $(p<0.05)$. On the contrary, in the general population different longitudinal studies have reported higher prevalence rates in men than women. ${ }^{11-13}$

Although, in both the contact groups, household and neighbourhood, the prevalence of the disease was higher among the contacts of smear positive sources $(7 \cdot 8 \%$ and $2 \cdot 8 \%)$ than in contacts of smear negative sources $(3.8 \%$ and $2.0 \%)$, the statistical analysis failed to show any significant relation between prevalence rates by type of contacts and bacteriological status of source $(p>0 \cdot 05)$. Thus on the basis of the findings of the study, it may be concluded that though the sputum positive patients pose a great problem to their contacts, the risk caused by smear negative patients cannot be overlooked and that the examination of contacts of smear negative patients is also essential simultaneously with those of smear positive patients. Our findings further suggest that the influence of a case is not limited to households only but extends to the neighbourhood also. Therefore, case detection among the people in the close surroundings of the case may be beneficial. Health programmes need to pay special attention to the higher risk caused by index cases to their contacts residing in close vicinity, although in overcrowded localities the possibility of getting infection from other places besides the index case may prevail.

The clustering of cases in certain pockets of the community is quite a usual finding. In the studied population out of 50 case clusters $32(64.0 \%)$ had multiple cases. The distribution of clusters according to number of secondary cases present was statistically significant $(p<0 \cdot 01)$. Distribution of secondary cases in the index case and suspect clusters was however, not so $(p>0.05)$. Various other epidemiological surveys have opined that quite a large number of bacillary cases are missed on examination of only one spot specimen. Furthermore about $30.0 \%$ genuine tuberculosis cases may be diagnosed, $10.0 \%$ by second spot sputum examination and $20.0 \%$ by culture examination. ${ }^{18}$ In the light of the present findings it may be pointed out that case detection among the contacts of index suspects cannot be 
ignored, especially where facilities for sputum culture are not available to differentiate further their bacteriological status.

A higher case yield $(\mathbf{8 0} \cdot 0 \%)$ among symptomatic contacts has been observed in the present study as against other population groups ${ }^{19}$-general population $(0 \cdot 8-2 \cdot 1 \%)$, cluster contacts $(2 \cdot 8 \%)$, and symptomatic contacts attending tuberculosis centres $(20 \cdot 6-54 \cdot 1 \%)$. Whereas the possibility of overdiagnosis by $x$ ray cannot be excluded, the yield of a high proportion $(30.8 \%)$ of bacteriologically confirmed cases $(44.5 \%$ among household and $25 \cdot 5 \%$ amongst neighbourhood) symptomatic contacts may be taken as remarkable observations.

\section{References}

${ }^{1}$ Sen PK. Incidence of tuberculosis in home contacts. Indian Journal of Tuberculosis 1959; 6: 111-5.

${ }^{2}$ Andrews RH, Devadutta S, Fox W, Radhakrishna S, Ramkrishnan CV, Velu S. Prevalence of tuberculosis among close family contacts of tuberculosis patients in South India and influence of segregation of patients on the early attack rate. Bull WHO 1960; 23: 463-510.

${ }^{3}$ WHO Tuberculosis Chemotherapy Centre. An investigation of household contacts of open cases of pulmonary tuberculosis amongst the Kibuyu in Kiambu, Kenya. Bull WHO 1961; 25: 831-50.

${ }^{4}$ Ramkrishnan CV, Andrews RH, Devadutta S, et al. Prevalence and early attack rate of tuberculosis among close family contacts of tuberculosis patients in South India under domiciliary treatment with isoniaszid plus PAS or isoniazid alone. Bull WHO 1961; 25: 361-407.

${ }^{5} \mathrm{Hsu}$ KHK. Contact investigation: a practical approach to tuberculosis eradication. Am J Public Health 1963; 53: 1761-9.

${ }^{6}$ Grzybowski S, Bernett GD, Styblo K. Contacts of cases of active pulmonary tuberculosis. Bull Int Union Tuberc 1975; 50: 90-106.
${ }^{7}$ Cocharan WC. Sampling techniques. New York: John Wiley and Sons Inc, 1963: 18-48.

${ }^{8}$ World Health Organisation. Expert committee on tuberculosis. Eighth Report, (WHO Tech Rep Ser 290.) Geneva: WHO 1964: 8-9.

${ }^{9}$ Cruickshank R. Mycobacterium. In: Cruickshank R, Duguid JP, Marmion BP, Swain RHA, eds. Medical microbiology. 12th ed. Edinburgh, London, and New York: Churchill Livingstone, 1975: 387-91.

${ }^{10}$ Gadekar NG. Radiology. In: Rao KN, Vishwanathan R, Deshmukh MD, et al, eds. Tuberculosis Association of India. Text book of tuberculosis. 2nd ed. New Delhi: Vikas Publishing house Pvt Ltd, 1981: 207-12.

${ }^{11}$ Indian Council of Medical Research. Tuberculosis in India-a sample survey 1955-58. Delhi: Government of India, 1959: 49-61. (Special report series 34.)

${ }^{12}$ Pamra SP, Goyal SS, Mathur GP. Changes in the prevalence and incidence of pulmonary tuberculosis in Delhi in recent years. Indian Journal of Tuberculosis 1973; 20: 57-64.

${ }^{13}$ Bagga AS, Krishnamurthy MS, Rangaswamy KR. Prevalence of tuberculosis disease and infection in Kadambathur Panchayat union, Chingleput district, South India. Indian Journal of Tuberculosis 1974; 21: 6-17.

${ }^{14}$ National Tuberculosis Institute. Tuberculosis in a rural population of South India: a five year epidemiologicalo survey. Bull WHO 1974; 51: 473-88.

${ }^{15}$ Krishnaswamy KV, Rahim MA, Parthasarthy R. Prevalence of tuberculosis in certain pockets in the city of Madras. Indian Journal of Tuberculosis 1978; 25:95-100.

${ }^{16}$ Gothi GD, Chakraborty AK, Nair SS, Ganpathy KT, Banerjee GC. Prevalence of tuberculosis in a South Indian district-twelve years after initial survey. Indian $\propto$ Journal of Tuberculosis 1979; 26: 121-35.

${ }^{17}$ Nair SS, Ramnathrao G, Chandrashekhar P. Distribution of tuberculosis infection and disease in clusters of rurato households. Indian Journal of Tuberculosis 1971; 18: 3-9.

${ }^{18}$ Anonymous. Tuberculosis prevalence [Editorial]. Indian? Journal of Tuberculosis, 1979; 26: 103-4.

${ }^{19}$ Nair SS, Gothi GD. Place of contact examination in a tuberculosis programme. Indian Journal of Tuberculosis 1973; 20: 164-72. 